\title{
TORT LIABILITY PROBLEMS OF SMALL MUNICIPALITIES
}

\author{
Grorge A. WARP*
}

The fear that the abolition of the tort immunity of municipal corporations would thrust an unbearable burden upon small municipalities is one of the chief obstacles in the way of further extension of liability. Until recently, no data existed in usable form which would tend either to prove or to disprove the basis of this fear. Indeed, the whole matter of tort liability in small towns and cities was shrouded in utter darkness. Fortunately, this deficiency has been relieved. The state-wide survey sponsored by the Bureau of Public Administration at the University of Virginia ${ }^{1}$ together with several studies of individual cities in other states ${ }^{2}$ have provided a basis upon which conclusions concerning the tort liability problems of small municipalities may be drawn.

The tort burden of small municipalities has been greatly exaggerated. Statistics based upon data from 189 municipalities with populations under 100,000 would seem to prove that the present burden of tort liability upon small municipalities is insignificant. The statistics are presented in the following table. ${ }^{3}$

TABLE I

Annual Tort Burden of Small Municipalities

\begin{tabular}{|c|c|c|c|c|c|}
\hline Municipality & $\begin{array}{l}1940 \\
\text { Pop. }\end{array}$ & $\begin{array}{l}\text { No. of } \\
\text { Awards }\end{array}$ & $\begin{array}{c}\text { Amt. of } \\
\text { Awards }\end{array}$ & $\begin{array}{l}\text { Aver. } \\
\text { Award }\end{array}$ & $\begin{array}{l}\text { Amt.per } \\
\text { I,O00 Pop. }\end{array}$ \\
\hline Austin, Tex. & $87,93^{\circ}$ & 13 & $\$ 2,96 \mathrm{r}$ & $\$ 228$ & $\$ 34$ \\
\hline Roanoke, Va. & 69,287 & 3 & 292 & 97 & 4 \\
\hline Madison, Wis. .. & 67,447 & - & 671 & - & Io \\
\hline Medford, Mass. .. & 63,083 & 32 & 10,205 & 319 & 162 \\
\hline Lynchburg, Va. ... & $44,54^{\mathrm{T}}$ & I6 & 2,404 & 150 & 54 \\
\hline x9 Virginia Cities & 273,170 & IO & 2,466 & 247 & 9 \\
\hline r65 Virginia Towns ... & $2 \pm 6,757$ & 6 & $r, 452$ & 242 & 7 \\
\hline
\end{tabular}

a Not including Roanoke and Lynchburg.

*A.B., 1935, A.M., I94I, LL.B., I939, Western Reserve University. Staff member, Bureau of Public Administration, University of Virginia. Author, Municipax. Tort Liability in Virginis (I94x); The Law and Administration of Municipal Tort Liability (1942) 28 VA. L. REv, 360; Can the "King" Do No Wrong? (1942) 31 NAT. MuNIc. Rev. $31 \mathrm{I}$.

1 Warp, Municipal Tort Liabilitix in Virginia (I94I).

${ }^{3}$ Unpublished studies by Mr. Gus Levy of Austin, Texas, and by Mr. Mark E. Gallagher of Medford, Massachusetts, both of which were sponsored by the Committce on Public Administration of the Social Science Research Council.

${ }^{3}$ The statistics are taken from the studies mentioned in notes I and 2, supra. 
It is readily apparent from these figures that the only municipality with a sizeable burden is the City of Medford, Massachusetts. And even there the annual burden is less than one and one-half cents per inhabitant. ${ }^{4}$

Tort burdens, of course, vary considerably as among municipalities within a given state and as among municipalities in different states. The variations may be explained in terms of size, climate, character of population, attitude of courts, customs of citizenry, and extent of municipal participation in proprietary functions. Large municipalities for the most part tend to have greater burdens in proportion to their populations than small municipalities. Northern municipalities tend to have larger burdens than southern. Municipalities with new and transient populations tend to have greater burdens than those with old and stable populations. The attitudes of judges and juries vary from state to state and from locality to locality, with all shades of bias represented. The inhabitants of some municipalities are socialistic and dependent; of others highly individualistic and independent. Some municipalities perform many proprietary functions; others-particularly the very small ones-only a few or none. Obviously the degree in which these various factors are present profoundly influences the tort burden of a given municipality.

In applying the law of tort liability to small municipalities public opinion plays a dominant role. The opinion of inhabitants in most municipalities is strongly opposed to suits against their community's government-an attitude perhaps based upon the fact that they consider themselves and their communities as one and the same. Accordingly, they exert all pressure they can bring to bear upon prospective litigants to discourage such actions.

The standard of care required of small municipalities differs, in practice, considerably from that required of large municipalities. It is common knowledge that streets are not kept in good repair. Sidewalks frequently are non-existent. One who is injured because of a sidewalk or street defect is considered careless. The area of a small municipality is so slight that its inhabitants are generally well aware of the defective conditions. Even if they do not know of a particular defect, they know of the prevalency of defects and, consequently, are expected to be vigilant.

"Fake" claims are almost unheard of in small municipalities. Everyone knows everyone else's business. Accordingly, if Mrs. Jones is injured because of the alleged negligence of municipal employees, all of her neighbors soon know the cause, nature, and extent of her injuries. And they know of Mrs. Jones' peculiarities and character, too. Such knowledge tends to defeat any action based upon fabricated facts or exaggerated injuries.

The Virginia survey ${ }^{5}$ reveals interesting data as to the nature of tort claims and awards in small municipalities. Prior to suit, the median tort claim in Virginia is $\$ 150$; after suit, $\$ 3,250$. The average administrative settlement before suit is $\$ 32$; after

\footnotetext{
I It is interesting to note further that the burdens of Austin, Texas, and Lynchburg, Virginia, are high because of the commendable policy of the city attorneys in those cities of settling all legitimate tort claims rather than of forcing them into the courts.

Supra note 1 .
} 
suit, $\$ 135$. And the average judgment is $\$ 50$. The great majority of the claims are based upon street and sidewalk defects. Of the claimants, one half were pedestrians, one fourth motor vehicle users, and the remainder property owners. Males and females were rather evenly divided, while 95 per cent were adults and a similar percentage were members of the white race.

Seventy-five per cent of the tortious acts concerned nonfeasance, less than one fourth misfeasance, and only a negligible number malfeasance. The number of claims for personal injuries tended to exceed the number for property damage, though the difference was not great. Indeed, in some municipalities there were more claims for property damage than there were for personal injuries.

Statistics on the disposition of claims are perhaps even more revealing. Of the claims filed, 60 per cent were rejected and not pressed; about one fourth were settled before suit was begun; and less than 20 per cent were litigated. Of the claims litigated, less than one fifth resulted in judgments for the claimant. Of the remainder, about 20 per cent were settled; about the same percentage were dismissed; and about 40 per cent resulted in judgments for the municipality. In other words, approximately $3^{\circ}$ per cent of the claimants received some sort of relief on their claims, either by settlement before or after suit or by judgment.

Three fourths of the claims were rejected. One half of these were turned down for the vague reason that the facts upon which they were based were insufficient to show negligence. One fourth were rejected because of the contributory negligence of the claimant. Inadequate notice of injury and no knowledge of defect each accounted for eight per cent of the rejections. And only six per cent of the claims were rejected because the function involved was governmental in nature. The small number of rejections on this latter ground is especially significant, in view of the fears expressed by some writers that the number might be large. It tends to show that the great bulk of tort cases are already within the scope of liability.

Law departments, even in small municipalities, play a dominant role in the administration of tort claims. In the great majority of cases, they are vested with what amounts to the final deciding authority. Their recommendations as to rejection, settlement, and litigation are seldom overruled. Indeed, most claimants apparently have no thought of prosecuting their claims beyond the administrative stage, for only about one seventh of them resort to litigation. It would seem that the greater number of claimants merely present their grievances and then stand by in the hope that the municipality, acting through its law department, will see that justice is done.

Almost without exception, the law departments of small municipalities consist of part-time attorneys whose municipal practices supplement their general practices. It is significant that in Virginia these part-time attorneys estimate that not more than five per cent of their municipal practices involve tort cases. Comparison of small municipalities with large cities reveals that the complexity of organization for administering the law of municipal tort liability multiplies as a municipality increases in 
size, the increase in organization being greater, proportionally, than the increase in population.

A few of the municipal attorneys have power to settle small claims without obtaining the approval of other officials. This grant of authority is always limited. For example, about 15 years ago, the City Council of Lynchburg, Virginia, passed a resolution authorizing the city attorney to settle tort claims where the amount of the settlement did not exceed $\$$ roo and directed the city treasurer to pay such sums out of unappropriated city funds. The purpose of the resolution was to provide a prompt and inexpensive remedy for those damaged by municipal acts and to do away with the publicity which naturally results when a claim is considered by the council or taken into the courts. In practice, the Lynchburg device has all but eliminated tort litigation against the city, thus more than paying for itself by the savings in court costs alone.

The need for protecting small municipalities from occasional large claims is more theoretical than real. It is-easy to say that a $\$$ ro,00o judgment against a village or town of 300 inhabitants would throw that village or town into bankruptcy. While such a judgment could probably be paid off with minimum hardship by means of a bond issue, the fact is that, to this writer's knowledge, such judgments are nonexistent. In order to uncover examples of individual hardships, the writer addressed inquiries to the executive secretaries of various municipal leagues. None of these men were able to cite cases where large tort judgments endangered the finances of municipalities. Indeed, many of them expressed the opinion that tort judgments formed a very small part of the municipal finance picture. The various administrative studies have revealed no instance of great hardship.

TABLE II ${ }^{6}$

Muntcipalities with Tort Burdens in Excess of \$25 per x,000 Population"

\begin{tabular}{|c|c|c|c|}
\hline Municipalities & $\begin{array}{l}\text { Amt.per } \\
\text { I,ooo Pop. }\end{array}$ & Municipalities & $\begin{array}{c}\text { Amt. per } \\
\text { t,ooo Pop. }\end{array}$ \\
\hline Virginia Beach, Va. & $\$ 192$ & Rocky Mount & $\$ 99$ \\
\hline Warrenton, Va. & .. $\quad 18 z$ & Lynchburg, V & 54 \\
\hline Harrisonburg, Va. & $\ldots$ I7I & Vinton, Va. & 43 \\
\hline Medford, Mass. & .. $\quad 162$ & Buena Vista, & 35 \\
\hline Falls Church, Va... & .. $13^{6}$ & Austin, Tex. & 34 \\
\hline
\end{tabular}

${ }^{2}$ Based on data from 189 municipalities.

The greatest hardship which this writer was able to locate was that of Virginia Beach, Virginia, where the total burden amounted to less than two cents per inhabitant. It would seem, of course, that among the thousands of cities, villages, and towns in the United States some hardships undoubtedly must arise. However, if they do, they are probably so rare as to be insignificant in a consideration of the whole field of municipal tort liability.

There are several courses open to those who would broaden the present scope of

${ }^{\circ}$ The statistics are taken from the studies mentioned in notes 1 and 2, suspra. 
tort liability but who, at the same time, would protect small municipalities from "theoretically" large judgments. The easiest way out would be to confer immunity upon all municipalities with, say, less than ro,ooo inhabitants. While this would unquestionably minimize the possibility of hardships on small cities, villages, and towns, it would do great injustices to individuals injured by tortious municipal acts. The other course would be to impose liability upon all municipalities, regardless of size, but to provide for insurance or for state aid. A state insurance fund probably would be most acceptable. It would spread the risk of unusual burdens and would in all probability be less expensive than insurance with private companies embracing less complete coverage. ${ }^{7}$ State aid, if it were undertaken, might consist of state assumption of all judgments over a certain amount or of all judgments over a certain percentage of a municipality's revenue. Regardless of whether insurance or state aid is undertaken, administrative settlement of claims should be encouraged.

It would seem that there is little cause for fear that an extension of liability to the performance of so-called governmental functions would bankrupt the small municipalities as a group. Statistics show that, as a whole, their tort burden is smaller than that for large cities, population considered. Abolition of governmental immunity probably would not increase the tort burden more than 15 or 20 per cent. Thus, while the theoretical burden of an individual small town would be increased by an extension of liability, the total burden for all of the municipalities in a state would evince only a slight rise. It would seem that the method of meeting the situation lies, not in keeping the law in its present unjust state, not in granting immunity to small municipalities, but in devising some form of state or cooperative insurance, perhaps made compulsory by statute.

${ }^{7}$ Staunton, Virginia, a city with a population of 13,337 , has been operating under a self-insurance scheme for the past 25 years. The scheme includes all types of coverage, except fire insurance. The insurance sinking fund now has a balance of $\$ 62,300$, although the city's contributions have totaled only $\$ 48,000$. For the past ro years claims against the fund have averaged $\$ 639$ annually, workmen's compensation accounting for 62 per cent, public liability claims for 20 per cent, and court costs for 18 per cent. Awards have ranged from 49 cents to $\$ 600$, with the average $\$ 145.78$. Warp, Staunton's Quarter Century of Self-Instuance (194I) 30 NAT. MUNIC. Rev. 608. 